\title{
Effect of dietary energy level on body weight, testicular development and semen quality of local barred chicken of the western highlands of Cameroon
}

\author{
Cyrille D’Alex Tadondjou*, Ferdinand Ngoula, Jean Raphael Kana, Henry Fuelefack Defang, \\ Herve Kuietche Mube, Alexis Teguia
}

Department of Animal Science, Faculty of Agronomy and Agricultural Sciences, University of Dschang, Dschang, Cameroon;

*Corresponding Author: cyralex2000@yahoo.fr

Received 5 July 2013; revised 20 September 2013; accepted 1 October 2013

Copyright (C) 2013 Cyrille D’Alex Tadondjou et al. This is an open access article distributed under the Creative Commons Attribution License, which permits unrestricted use, distribution, and reproduction in any medium, provided the original work is properly cited.

\section{ABSTRACT}

This study was designed to examine the effects of dietary energy levels on some growth and reproductive parameters of local barred chickens in Cameroon. For this purpose, One hundred and forty four day-old barred male chicks, weighing $28.33 \mathrm{~g}$ in average were randomly divided into 12 groups of 12 chicks each. Three feeding programs (FP) comprising each a starter diet from day old to 12 weeks (S0: $2800 \mathrm{Kcal} / \mathrm{Kg}$; S1: 2900 $\mathrm{Kcal} / \mathrm{Kg}$; S2: $3000 \mathrm{Kcal} / \mathrm{Kg}$ ) and grower diet from 13 to 20 weeks (G0: $2900 \mathrm{Kcal} / \mathrm{Kg}$; G1: $3000 \mathrm{Kcall}$ $\mathrm{Kg}$; G2: $3100 \mathrm{Kcal} / \mathrm{Kg}$ ) were used and designated FP1, FP2 and FP3 respectively. Each of the FP was randomly allotted of 4 groups of 12 birds in a completely randomized design. Throughout experiment ( 1 day old to 20 weeks), body weight was recovered every 2 weeks. At 20 weeks of age, roosters were sacrificed; semen characteristic was analyzed and testes were characterized. Between 2 to 10 weeks old, body weight of cocks fed with FP3 was significantly higher $(P<0.05)$ as compared to others FP. Inversely, from 12 to 20 weeks, body weight of cocks receiving FP1 was significantly higher $(P<0.05)$ than that of cocks receiving feeding programs 2 and 3 . At 20 weeks, $100 \%$ of cocks fed on FP3 produced semen versus $66.66 \%$ and $16.66 \%$ respectively for those on FP1 and FP2. Semen volume and mass motility of cocks fed on FP3 or FP1 were significantly (P $<0.05$ ) higher than FP2. It was concluded that FP1 had more suitable dietary energy levels for growth and reproduction of local barred cocks.
Keywords: Energy; Body Weight; Testes; Semen; Puberty; Local Barred Chicken

\section{INTRODUCTION}

Local chickens are characterized by good adaptability to the hard tropical environment, slower growth rate, poor laying ability and smaller egg size compared to the exotic breed; In addition, they possess good mothering ability and resistance to diseases [1]. In developing countries, many studies attempted to evaluate the genetic potential of the indigenous birds under improved management conditions [2-7]. Most of works tended to overlook behavioral and reproductive traits, which are important under village production environment [1]. However, one of the most important objectives of poultry breeding in village condition is the production of chicks since they are highly demanded in the market. Chick's production highly depends on flock fertility. As it has been reported, semen quality can impact egg fertility and subsequently egg hatchability [8]. According to Sarah [9], fertility in a breeder flock can be improved by using males with high sperm quality. Upendra et al. [10] reported that semen quality is positively correlated with percentage of fertile eggs and hatchability. The semen quality in poultry gives an excellent indicator of their reproductive potential [11, 12]. Usually, assessing fertilizing potential of semen includes sperm morphology, motility, concentration, viability, ability of acrosome to penetrate oocytes, the specific conductivity of the ejaculate $[13,14]$. However, sperm viability, concentration and motility are the major components of routine quality assessment $[12,14]$. These components are under the control of many factors including feeding. 
Dietary energy level has been reported by many authors to affect performance trait such as body weight, delayed sexual maturity, semen production and quality in the male bird [15-17]. It has been reported that hypoenergetic diet leads to excessive weight gain $[17,18]$ and consequently induce early sexual maturity and reduce fertility in male broiler [17]. Kirby et al. [19] reported that increase in calorie intake may lead to an increase in testes weight with no apparent increase in spermatogenic efficiency. Adequate nutrition is therefore essential to maintain the breeding flock in good reproductive condition [17]. Age at sexual maturity has long been considered as an important factor that determines fecundity trait and affects subsequent performances [20-22]. In cock flock, Brière et al. [17] reported that sexual precocity is related to early testicular regression. Kirk et al. [23] and Walsh and Brake [24] revealed that one of the major problems encountered with commercial broiler breeder flocks has been the often dramatic decrease in fertility during the latter part of laying period, particularly after 50 weeks of age. This could be associated with decrease in semen quality. Several studies on semen characteristics of African local cocks have been published $[25,26]$ but none of them reports on Cameroon chickens which constitutes approximately $56 \%$ of the chicken population in the country [27]. Moreover, there is no information on nutritional requirements of these birds. The aim of the present study was therefore to evaluate the effect of dietary energy level on body weight, testicular development and semen characteristic of local barred cocks of the Western Region of Cameroon.

\section{MATERIALS AND METHODS}

\subsection{Study Area}

The study was carried out between February and September 2012 at the Teaching and Research Farm of the University of Dschang (LN 5 to $7^{\circ}$, LE 8 to $12^{\circ}$ ). Dschang is located in the Western Sudanoguinean Savanna of Cameroon at $1500 \mathrm{~m}$ above sea level. Mean wind speed is $1.60 \mathrm{~m} / \mathrm{s}$; mean temperature is $20^{\circ} \mathrm{C}$ and relative humidity generally exceeds $60 \%$. Annual rainfall varies between 1910 and $2010 \mathrm{~mm}$. The raining season goes from mid-March to mid-November and the dry season from mid-November to mid-March.

\subsection{Experimental Animals}

One hundred and forty four day-old barred male chicks, weighing $28.33 \mathrm{~g}$ in average were randomly divided into 12 groups of 12 chicks each. Chicks were housed in raphia bamboo made cages and kept under similar environmental and managerial conditions during experiment. Feed and water were given ad libitum in adapted equipments.

\subsection{Experimental Diets and Design}

Three feeding programs comprising each a starter diet from day old to 12 weeks (S) and grower diet from 13 to 20 weeks $(\mathrm{G})$ were drawn as reported in Table 1.

Each of the feeding programs was randomly allotted of 4 groups of 12 birds in a completely randomized design.

\subsection{Data Collection}

Live body weight was recorded every two weeks.

At 20 weeks of age, 8 cocks per treatment were randomly chosen and sacrificed by decapitation. Semen was collected immediately after sacrifice by slight finger pressure on spermiductus from epididymalductus till the base of the phallus. The number of cocks producing semen was recorded together with volume and color of the

Table 1. Percentage composition and calculated chemical components of experimental diets.

\begin{tabular}{ccccccc}
\hline & \multicolumn{2}{c}{$\begin{array}{c}\text { Feeding } \\
\text { program 1 }\end{array}$} & \multicolumn{2}{c}{$\begin{array}{c}\text { Feeding } \\
\text { program 2 }\end{array}$} & \multicolumn{2}{c}{$\begin{array}{c}\text { Feeding } \\
\text { program 3 }\end{array}$} \\
\cline { 2 - 7 } Ingredients & $\mathrm{S} 0$ & $\mathrm{G} 0$ & $\mathrm{~S} 1$ & $\mathrm{G} 1$ & $\mathrm{~S} 2$ & $\mathrm{G} 2$ \\
& $\mathbf{2 8 0 0}$ & $\mathbf{2 9 0 0}$ & $\mathbf{2 9 0 0}$ & $\mathbf{3 0 0 0}$ & $\mathbf{3 0 0 0}$ & $\mathbf{3 1 0 0}$ \\
& Kcal & Kcal & Kcal & Kcal & Kcal & Kcal \\
\hline Corn meal & 42.0 & 47.0 & 48.0 & 49.0 & 43.0 & 45.0 \\
Wheat bran & 22.5 & 22.0 & 16.5 & 22.0 & 20.0 & 22.0 \\
Cotton seed & & & & & & \\
cake & 8.0 & 9.0 & 8.0 & 8.0 & 8.0 & 6.0 \\
Soybean cake & 15.0 & 11.0 & 15.0 & 7.0 & 15.0 & 13.0 \\
Fish meal & 6.0 & 3.0 & 6.0 & 6.5 & 6.0 & 3.0 \\
Bone meal & 0.0 & 2.0 & 0.0 & 1.5 & 0.0 & 1.5 \\
Shellfish & & & & & & \\
powder & 1.5 & 5.0 & 1.5 & 5.0 & 1.5 & 5.0 \\
Premix 5\% ( $)$ & 5.0 & 0.0 & 5.0 & 1.0 & 5.0 & 3.5 \\
Palm oil & 0.0 & 1.0 & 0.0 & 0.0 & 1.5 & 1.0 \\
Total & 100.0 & 100.0 & 100.0 & 100.0 & 100.0 & 100.0 \\
Crude protein (\%) & 23.66 & 20.78 & 23.27 & 20.70 & 23.43 & 20.34 \\
ME (kcal/kg) & 2803.9 & 2936.03 & 2913.73 & 3013.51 & 3006.173100 .95 \\
Calcium (\%) & 1.49 & 1.74 & 1.48 & 1.51 & 1.49 & 1.55 \\
Phosphor (\%) & 0.76 & 0.74 & 0.69 & 0.73 & 0.71 & 0.74 \\
\hline Lysine (\%) & 1.31 & 1.06 & 1.29 & 1.10 & 1.49 & 1.06 \\
& 0.43 & 0.40 & 0.43 & 0.40 & 0.43 & 0.46 \\
\hline
\end{tabular}

${ }^{*}$ Premix 5\%: crude protein $=40 \%$; Metabolizable energy $=2078 \mathrm{kcal} / \mathrm{kg}$; Calcium $=8 \%$; Phosphor $=2.05 \%$; Lysine $=3.30 \%$; Met (Methionine) $=$ $2.40 \%$; ME $=$ Metabolizable energy. 
sample. The collected semen was maintained at $38^{\circ} \mathrm{C}$ $40^{\circ} \mathrm{C}$ using a water bath for sperm motility assessment and sperm density. The left and right testes were also removed, cleaned from adhesive tissue, and testes measurements were recorded. The left testis diameter and height were measured. The testicular shape index was obtained by dividing testicular diameter by testicular height.

The collected semen was analyzed as described by Ngoula et al. [28] and Hafez [29].

\subsection{Statistical Analysis}

Data collected were subjected to one way analysis of variance (ANOVA) at $\mathrm{P}<0.05$. When differences were significant between means, Duncan multiple range test were used to separate means. Pearson correlation coefficient for some parameters was also performed at $\mathrm{P}<0.05$. All statistical analyses were performed using SPSS 12.0.

\section{RESULTS}

\subsection{Effect of Dietary Energy Level on Body Weight}

Figure 1 presents the evolution of live body weight of cocks during the experiment. Between 2 and 10 weeks, body weight of cocks receiving feeding programs 3 (FP3) was significantly higher $(\mathrm{P}<0.05)$ than that of animals

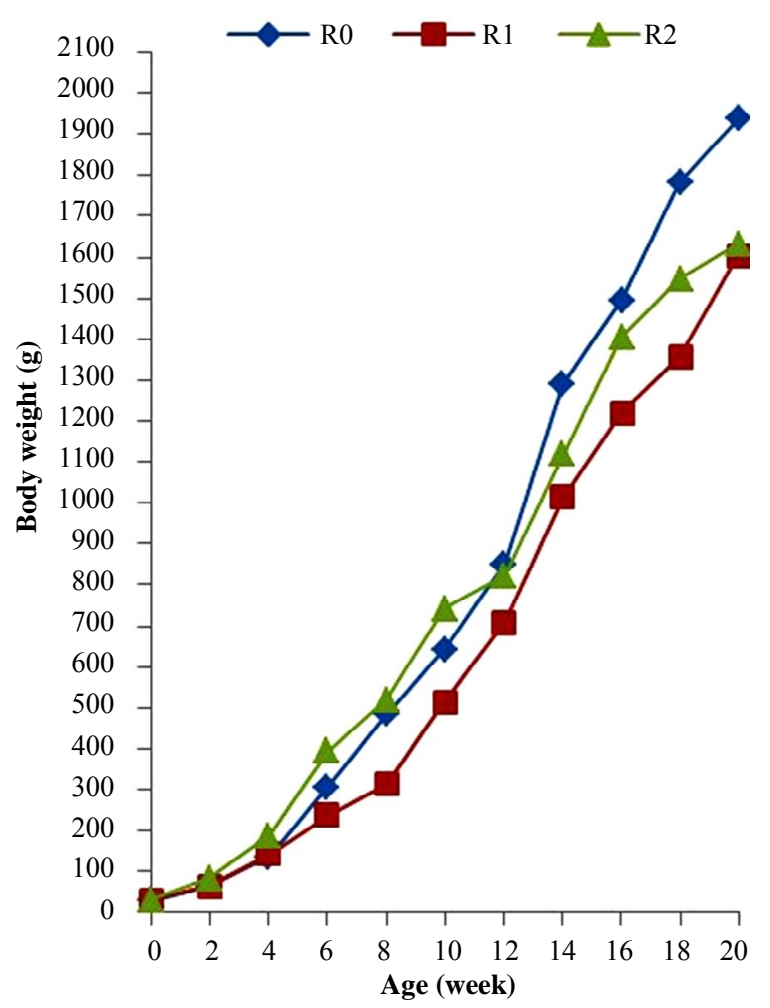

Figure 1. Growth curve of local barred cocks fed graded energy levels. Each point represents means \pm ESM; n = 12 . fed with feeding programs 1 (FP1) and 2 (FP2). Inversely, from 12 to 20 weeks, body weight of cocks receiving FP1 was significantly higher than that of cocks receiving FP2 and FP3. The lowest body weight was recorded with FP2 from the beginning to the end of the experiment period.

\subsection{Effect of Dietary Energy Level on Testicular Development}

The summary of the analysis of variance as presented in Table 2 indicated that dietary energy level had significant effect on testicular weight $(\mathrm{P}<0.05)$. The left and right testes weights recorded on FP3 and 1 were significantly higher $(\mathrm{P}<0.05)$ compared to testes weight of cocks fed on FP2. However, no significant difference was found between treatments neither for testicular shape index nor left-right testicular weight ratio. A highly positive and significant correlation was found between body weight at 4 weeks and testicular weight in cocks fed with FP3 ( $\mathrm{r}=0.896, \mathrm{P}<0.05)$. In addition, in cocks fed on FP1, a highly positive correlation was recorded between body weight at 8 weeks and testicular weight $(r=0.802)$.

\subsection{Effect of Dietary Energy Level on Puberty and Semen Characteristics}

Table 3 summarizes the effects of dietary energy level on percentage of cocks producing semen at 20 weeks, and semen characteristics. All the cocks (100\%) receiving FP3 versus $66.66 \%$ and $16.66 \%$ respectively of cocks receiving FP2 and FP1 produced semen at 20 weeks. The semen volume and spermatozoa mass motility of cocks fed on FP3 and FP1 were significantly higher $(\mathrm{P}<0.05)$ compared to cocks fed on FP2. The sperm density was not significantly affected by the dietary energy level $(\mathrm{P}>$ 0.05). However, cocks fed on FP1 had the relative highest value of sperm density. Semen color remained unchanged irrespective of treatment $(\mathrm{P}>0.05)$.

Table 2. Effect of dietary energy level on testicular development.

\begin{tabular}{cccc}
\hline Parameters & FP1 $(\mathrm{n}=8)$ & FP2 $(\mathrm{n}=8)$ & FP3 $(\mathrm{n}=8)$ \\
\hline Paired testis weight & $12.04 \pm 2.69^{\mathrm{b}}$ & $5.73 \pm 1.41^{\mathrm{a}}$ & $15.35 \pm 0.20^{\mathrm{b}}$ \\
Left testicular weight & $6.90 \pm 1.69^{\mathrm{b}}$ & $3.01 \pm 0.82^{\mathrm{a}}$ & $8.43 \pm 0.1^{\mathrm{b}}$ \\
Right testicular weight & $5.48 \pm 1.23 \mathrm{~b}$ & $2.54 \pm 0.65^{\mathrm{a}}$ & $6.91 \pm 0.27^{\mathrm{b}}$ \\
$\begin{array}{c}\text { Testicular shape index } \\
\begin{array}{c}\text { Left-right testicular } \\
\text { weight ratio }\end{array}\end{array}$ & $0.582 \pm 0.008^{\mathrm{a}}$ & $0.588 \pm 0.014^{\mathrm{a}}$ & $0.574 \pm 0.005^{\mathrm{a}}$ \\
\hline
\end{tabular}

Means in the same line with different letters are significantly different $(\mathrm{P}<$ $0.05)$. 
Table 3. Effect of dietary energy level on puberty and semen characteristics.

\begin{tabular}{cccc}
\hline Parameters & FP1 $(\mathrm{n}=8)$ & FP2 $(\mathrm{n}=8)$ & FP3 $(\mathrm{n}=8)$ \\
\hline $\begin{array}{c}\text { Cocks producing } \\
\text { semen at 20 weeks (\%) }\end{array}$ & 66.66 & 16.66 & 100 \\
Mass Motility & $3.37 \pm 0.185^{\mathrm{b}}$ & $2.00 \pm 0.158^{\mathrm{a}}$ & $2.90 \pm 0.187^{\mathrm{b}}$ \\
Individual Motility & $3.87 \pm 0.243^{\mathrm{a}}$ & $2.33 \pm 0.241^{\mathrm{a}}$ & $2.20 \pm 0.200^{\mathrm{b}}$ \\
Sperm density $\left(10^{9} / \mathrm{mL}\right)$ & $6.59 \pm 1.301^{\mathrm{a}}$ & $3.33 \pm 0.064^{\mathrm{a}}$ & $5.42 \pm 1.774^{\mathrm{a}}$ \\
Volume (ml) & $0.216 \pm 0.047^{\mathrm{b}}$ & $0.08 \pm 0.008^{\mathrm{a}}$ & $0.208 \pm 0.045^{\mathrm{b}}$ \\
Color & $1^{\mathrm{a}}$ & $1^{\mathrm{a}}$ & $1^{\mathrm{a}}$ \\
\hline
\end{tabular}

Means in the same line with different letters are significantly different $(\mathrm{P}<$ $0.05)$.

\section{DISCUSSION}

Body weight of cocks receiving the lowest energy level (FP1) at 20 weeks was significantly higher than that of cocks receiving respectively the intermediate (FP2) and highest (FP3) energy level. It is well established that hypo energetic diet leads to excessive weight gain [18,30, 31]. Birds fed with low metabolizable energy diet consume more nutrients than needed, particularly protein, vitamins and minerals. They then increase their caloric intake by using part of the diet protein as source of energy without affecting the protein quantity necessary for growth $[10,11,30]$. Hyper energetic diet doesn't cover quantitatively other nutritive needs such as protein, vitamins and minerals. The deficiency may negatively impact growth [18,30,31]. Body weight evolution between 2 and 10 weeks showed significantly higher values for cocks receiving feeding programs 3 . This result is in agreement with the findings of Teteh et al. [32] who pointed out that the faster growth rate of chicks fed with high metabolizable energy diet may be due to the use of energy for efficient retention of protein; since protein is the building blocks needed for growth.

This study revealed that dietary energy level affected testicular development. In fact, testicular development was significantly higher with FP3 and FP1 compared with feeding programs 2. This may be attributed to growth dynamic within the first 10 weeks. The highest (FP3) and the lowest (FP1) dietary energy level lead to an increase of testes weight. In fact, it is well established that bird fed hypo-energetic diet uses a part of the diet protein as source of energy to compensate and then increase caloric intake $[18,32]$, suggesting that high energy intake leads to precocious testicular development and testicular hypertrophy. The testicular development of roosters with high body weight at 8 weeks was significantly higher than that of other cocks. This result supported the findings of Brière et al. [17] and El-Dlebshany [23] who reported that high growth performance leads to early sexual ma- turation. High body weight gain during prepubertal period seems to involve an acceleration of the increase in testes size. This could be associated with the development of seminiferous tubules in testes. In fact, during prepubertal period, testicular development is highly correlated to the number and size of Sertoli cells while during pubertal period; it is rather correlated to the number of germinal cells. This is in agreement with Kirby et al. [19] who reported an increase of testis weight with no apparent increase in spermatozoa production. This work also revealed that $66.66 \%$ of cocks receiving the lowest (FP1) versus $100 \%$ of cocks receiving the highest (FP3) energy level started producing semen at 20 weeks. Testes produce both sperm and part of seminal plasma suggesting that testis development is not only associated with Sertoli cell proliferation but also with establishment of spermatogenesis activity [33]. This result also suggests that high energy intake accelerates prepubertal development, advance spermatogenesis and hence early puberty.

Semen characteristics of roosters fed with the highest dietary energy (FP3) were relatively lower when compared to those of cocks fed with the lowest dietary energy (FP1). In birds, Brière et al. [17] reported that intratesticular hyperthermia resulting from high dietary energy intake may lead to reduction of sperm production. Intratesticular hyperthermia acts by altering the functional state of spermatogonia stock [17]. High dietary energy can reduce sperm production by decreasing the ability of spermatogonia to develop into spermatocyte I and II. The sperm density of cocks receiving the lowest and the highest dietary energy level were higher than those reported by Peters et al. [34] in Nigerian indigenous, white leghorn and giriraja cocks. The differences in sperm density could be associated with dietary energy level since FP2 which produced similar results as reported by Peters et al. [34] is the standard diet used to feed white leghorn. The semen volumes recorded in this work are in agreement with Sauveur [35] who indicated that semen volume of light stump cock ranges between 0.1 to $0.8 \mathrm{ml}$.

\section{CONCLUSION}

The presented results suggested that testicular development and sexual maturity are affected by dietary energy level. This work generated first data of semen characteristic from Cameroonian local chicken. Feeding programs 1 seems to be more interesting for both growth and reproductive performances but further work is required for accurate conclusion.

\section{REFERENCES}

[1] Dessie, T., Taye, T., Dana, N., Ayalew, W. and Hanotte, O. (2011) Current state of knowledge on phenotypic characteristics of indigenous chickens in the tropics. World's 
Poultry Science Journal, 67, 507-516. http://dx.doi.org/10.1017/S0043933911000559

[2] Van Marle-Koster, E. (2001) Genetic and phenotypic characterization of native fowl population in South Africa. Ph.D. Thesis, University of Pretoria.

[3] Tadelle, D. (2003) Phenotypic and genetic characterization of local chicken ecotypes of Ethiopia. Ph.D. Thesis, Humboldt University.

[4] Keambou, T.C., Manjeli, Y., Tchoumboue, J., Teguia, A. and Iroume, R.N. (2007) Caractérisation morphobiométrique des ressources génétiques de poules locales des hautes terres de l'Ouest Cameroun. Livestock Research for Rural Development, 19, 107.

[5] El-Yuguda, A.D., Baba, S.S., Ibrahim, U.I. and Brisibe, F. (2009) Maladie de Newcastle et maladie de Gumboro chez les poulets villageois dans l'Etat de Borno (Nigeria). Aviculture Familiale, 18, 18-27.

[6] Fotsa, J.C., Bordas, A., Rognon, X., Tixier-Boichard, M., Poné, K.D. and Manjeli, Y. (2007) Caractérisation des élevages et des poules locales et comparaison en station de leurs performances à celles d'une souche commerciale de type Label au Cameroun. Septièmes journées de la Recherche Avicoles, Tours, 28 et 29 Mars 2007.

[7] Fotsa, J.C., Rognon, X., Tixier-Boichard, M., Coquerelle, G., Poné, K.D., Ngou Ngoupayou, J.D., et al. (2010) Caractérisation phénotypique des populations de poules locales (Gallus Gallus) de la zone forestière dense à pluviométrie bimodale du Cameroun. Animal Genetic Resources, 46, 49-59. http://dx.doi.org/10.1017/S207863361000069X

[8] Brillard, J.P. (2003) Practical aspects of fertility in poultry. World's Poultry Science, 59, 441-446.

[9] Sarah, M. (2001) Selecting males by sperm quality. World Poultry-Elsevier, 17, 32-34.

[10] Upendra, H.A., Mitra, S.K. and Suryanayana, T. (2000) Effect of speman vet powder on semen quality and hatchability in poultry. The Veterinarian, 24, 23.

[11] Peters, S.O., Omidiji, E.A., Ikeobi, C.O.N., Ozoje, M.O. and Adebambo, O.A. (2004) Effect of naked neck and frizzled genes on egg traits, fertility and hatchability in local chicken. Self Sufficiency of Animal Protein in Nigeria. Proceedings of the 9th Annual conference of Anim. Sci. Assoc. Nig., Ebonyi State University, Abakaliki, 262-264.

[12] Parker, H.M. and McDaniel, C.D. (2004) The optimum semen dilution for the sperm quality index that is most predictive of Broiler Breeder fertility. International Journal of Poultry Science, 3, 588-592.

http://dx.doi.org/10.3923/ijps.2004.588.592

[13] Máchal, L. and Krivánek I. (2001) Indicators of semen quality of roosters of three parental layer lines and specific conductivity of the semen. Acta Veterinaria Brno, 71, 109-116. http://dx.doi.org/10.2754/avb200271010109

[14] Nering, S., Vita, R., Aloyzas, J., Henrikas, Z. and Magnus, A. (2009) Assessment of sperm quality traits in relation to fertility in boar semen. Acta Veterinaria Scandinavica, 51, 1.

[15] Romero-Sanchez, H., Plumstead, P.W., Leksrisompong, N., Brannan, K.E. and Brake, J. (2008) Feeding Broiler
Breeder males. 4. Deficient feed allocation reduces fertility and broiler progeny body weight. Poultry Science, 87, 805-811. http://dx.doi.org/10.3382/ps.2007-00285

[16] Ghonim, A.I.A., Awad, A.L., Kout, E. and Moustafa, M. (2010) Effect of feeding different levels of energy and crude protein on semen quality and fertility of Domyati Ducks. Egyptian Poultry Science, 30, 583-600.

[17] Brière, S., Brillard, J.P., Panheleux, M. and Froment, P. (2011) Alimentation, fertilité et bien-être des oiseaux reproducteurs domestiques: Des liens complexes. INRA Productions Animales, 24, 171-180.

[18] Marie, Y.A., Ibrahim, M.A., Mahmoud, M.A. and AbouKhashaba, H.A. (2009) Influence of nutrient density on productive and reproductive performance of some local laying hen strains. Egyptian Poultry Science, 29, 527-564.

[19] Kirby, J.D., Mankar, M.V., Hardesty, D. and Kreider, D.L. (1996) Effects of transient prepubertal hypothyroidism on testis development and function in the domestic fowl. Biology Reproduction, 55, 910-916.

http://dx.doi.org/10.1095/biolreprod55.4.910

[20] Camci, Ö., Erensayin, C. and Aktan, S. (2002) Relations between age at sexual maturity and some production characteristics in quails. Archives of Geflvgelk, 66, 280-282.

[21] Meky, M.A.M. (2007) Effect of age at sexual maturity on some production traits of Japanese quails. M. Sc. Thesis, Faculty of Agriculture, Alexandrie University.

[22] El-Dlebshany, E.A. (2008) The relationship between age at sexual maturity and some productive traits in local chickens strain. Egyptian Poultry Science, 28, 1253-1263.

[23] Kirk, S., Emmans, G.C., McDonald, R. and Arnist, D. (1980) Factors affecting hatchability of eggs from broiler breeders. British Poultry Science, 21, 37-43. http://dx.doi.org/10.1080/00071668008416633

[24] Walsh, T.J. and Brake, J. (1997) The effect of nutrient intake during rearing of broiler breeder females on subsequent fertility. Poultry Science, 76, 297-305.

[25] Saeed, J.M. and Al-Soudi, K.A. (1975) Seasonal variation in semen characteristics of White Leghorn, New Hamphire and indigenous chickens in Iran. British Poultry Science, 16, 91-102.

[26] Omeje, S.S.I. and Marine, B.N. (1990) Evaluation of semen characteristics of adult cocks of different genetic background. Theriogenology, 24, 1111-1118. http://dx.doi.org/10.1016/S0093-691X(05)80010-X

[27] MINEPIA (2008) Donnéesstructurelles.

[28] Ngoula, F., Tebug, T.T., Kenfack, A., Defang, F.H., Tendonkeng, F. and Pamo, T.E. (2012) Effects of Buck Age, Storage Duration, Storage Temperature, and Diluent on Fresh West African Dwarf Buck Semen. Journal of Reproduction and Infertility, 3, 58-66.

[29] Hafez, E.S.E. (1987) Reproduction in Farm Animals. 5th Edition, Lea and Febiger, Philadelphia, 315-481.

[30] Moreng, R.E. and Avens, J.S. (1985) Poultry science and production. Reston Publishing Company, Inc. Reston, Virginia, 203-234.

[31] Lee, C.I. (2009) Poultry Nutrition and feeding. Animal Nutrition Handbook, 316-331. 
[32] Teteh, A., Tona, K., Aklikokou, K., Gbeassor, M., Buyse, J. and Decuypere, E. (2010) Effects of low-protein or high energy levels diets on layer-type chick juvenile performance. International Journal of Poultry Science, 9, 11561160. http://dx.doi.org/10.3923/ijps.2010.1156.1160

[33] Lüpold, S., Wistbutba, J., Damm, S.O., Rivers, W.J. and Birkhead, R.T. (2011) Sperm competition leads to functional adaptations in avian testes to maximize sperm quantity and quality. Reproduction, 141, 595-605.

http://dx.doi.org/10.1530/REP-10-0501
[34] Peters, S.O., Shoyebo, O.D., IIori, B.M., Ozoje, M.O., Ikeobi, C.O.N. and Adebambo, O.A. (2008) Semen quality traits of seven strains of chickens raised in the humid tropics. International Journal of Poultry Science, 7, 949953. http://dx.doi.org/10.3923/ijps.2008.949.953

[35] Sauveur, B. (1988) Reproduction des volailles et production d'œufs. INRA, Paris. 